$<$ 原 著 $>$

肝内小結節性病変の診断を目的とした高速 MRI の臨床応用 （息止め MRI 検査の有用性について）

\begin{tabular}{|c|c|c|c|c|c|c|}
\hline 斎藤 & 聡 & 池田 & 健次 & 鯉田 & 勲 & 鈴木 \\
\hline 木 & 正宏 & 坪田 & 昭人 & 荒瀬 & 康司 & 茶山 \\
\hline & 直哉 & 熊田 & 博光* & & & \\
\hline
\end{tabular}

要 旨：高速 MRI にて慢性肝疾患に合併した肝内小結節性病変の診断を試みた。対象柱慢性 肝疾患を合併した, 腫瘤径 $20 \mathrm{~mm}$ 以下の)肝細胞癌 (HCC) 78結節, 腺腫梯過形成 $(\mathrm{AH}) 16$ 結節, 粗大再生結節 (LRN) 26結節，肝血管腫 (CH) 29結節である。すべて息止め市で，T1強調画 像, T2強調画像をファーストスピンエコー法て撮像し, 引き続いて Gadolinium-DTPA 急速静 注下でダイナミックMRI（Fast multiplanar spoiled GRASS 法）を撮像した。をれぞれ20秒 前後の息止めにて施行し，検査時間は約15分であった. T1強調画像，T2強調画像のいずれかで 高信号もしくは低信号病変として検出されたのは HCC $92 \%$, AH $56 \%$, LRN $37 \%$, CH 100\%, ダイナミック MRI で早期濃染は HCC $74 \%$, AH $0 \%, \mathrm{LRN} 0 \%, \mathrm{CH} 3 \%, 5$ 分後の晚期 濃染は HCC $0 \%$, AH 0\%, LRN 0\%, CH 97\%であった。高速 MRI は短時間施行でき， 侵撉も少なく, 肝内小結節性病変の診断には感度, 特異度共に高く有用な検查法と考えられた。

索引用語： MRI 肝細胞癌 肝血管腫

\section{緒 言}

わが国では肝細胞癌が増加傾向にあり，肝癌の早期 診断は臨床上重要な問題である゙ー3).肝癌の診断は現在 おもに腹部超音波やX $\mathrm{X}$ 線 CTによりなされてい $3^{4.5)}$. 一方, MRI 《非侵襲的で肝癌や肝癌類似性病変 の診断能も良好とされてきたが6 8), 従来のスピンエ コー法による検查は検查時間がかかり実際には臨床的 にはあまり多くの検査が施行できなかった，しかしな がら, MRIも撮影装置の進歩や撮影方法の開発により 高速撮影が可能となり短時間で検查が可能となり,さ らに息止め検査も可能となりこれまでのMRIでは 問題であった時間分解能か大幅に改善され ${ }^{9 \sim 12)}$, 従来 の肝癌に対する高い検出率を保ったままで日常臨床に 役立つ検榃法として確立することも可能となった。そ こで今回我々は高速 MRI を用いることにより早期肝 癌の誩断を目標に肝内小結節性病変の診断にどの程度 有用かについて検討したので報告する。

\section{対象と方法}

対象は慢性肝疾患を合併した腫溜径 $20 \mathrm{~mm}$ 以下の肝 内小結節性病変で, 肝細胞癌65例, 78結節, 腺腫様過 形成16例，16結節，粗大再生結節24例，27結節, 肝血 管腫25例，29結節である。診断は腺腫様過形成，再生 結節はすべて肝生検もしくは切除による組織学的診断 とし, 肝緇胞癌と肝血管腫は組織彭もしくは血管造影 により典型的な濃染像を呈した症例とした ${ }^{13)}$ ．腺腫様 過形成, 粗大再生結節, 肝血管腫はいずれも 4 力月以 上経過観察を行った。なお以上の診断基準を満たさな い症例はすべて除外した，基礎疾患としては肝硬変の 合併はそれぞれ肝細胞癌60例 (92\%)，腺腄様過形成 16 例 $(100 \%)$ ，粗大再生結節 24 例 $(100 \%)$ ，肝血管腫 20 例 $(80 \%)$ であり, 慢性肝炎は肝細胞癌 5 例 (8\%), 肝血管腫 5 例（20\%）であった。

MRI 装置は GE 社製 Signa Advantage $1.5 \mathrm{~T}$ 超伝 導装置を使用した，MRI の撮像方法は T1強調画像は

Satoshi SaItoh, Kenji IKeda, Isao Kolda, Yoshiyuki Suzuki, Masahiro Kobayashi, Akihito Tsubota, Yasuji Arase, Kazuaki Chayama, Naoya Murashima, Hiromitsu KumadA*

"虎の門病院消化器科

<受付日1996年3 月15日> 
ファーストスピンエコー(FSE 法 $)^{\text {9.11) }}$ を用い, TR 400 msec, 実効 TE17msec, エコートレイン 4, FOV $32 \times$ $24,8 \mathrm{~mm}$ 厚, $2 \mathrm{~mm}$ ギャップ, matrix $256 \times 192,1 \mathrm{NEX}$, flow compensation $り$, spatial presaturation は superior + inferior で 3 枚毎に15秒の息止め $4 \sim 5$ 回 にて全肝を撮像した。 T2強調画像も FSE 法を用いて TR 2,660msec, 実効 TE 91msec, エコートレイン19, FOV $32 \times 26,10 \mathrm{~mm}$ 厚, $0 \mathrm{~mm}$ ギャップ, matrix $256 \times$ 192, 1NEX, flow compensation あり, spatial presaturation $は$ superior + inferior, fat suppression ありで 7 枚毎に27秒の息止め 2 回にて全肝を撮像し た.ダイナミック MRIは Fast mutiplanar spoiled GRASS (FMPSPGR) 法を用いて ${ }^{12)}$, TR 160msec, TE $3.4 \mathrm{msec}$, flip angle $70^{\circ}$, FOV $35 \times 26,10 \mathrm{~mm}$ 厚, 0mm ギャップ, matrix $256 \times 160$, $1 \mathrm{NEX}$, spatial presaturaition は superior+inferior で14枚を22秒の 息止めにて全肝を撮像した. 造影剂は $0.2 \mathrm{~m} l / \mathrm{kg} の$ Gadolinium-DTPA（Gd-DTPA）を急速に静注し，静 注前, 20 秒後, 60 秒後, 120 秒後, 5 分後に繰り返して
撮像した.なお検查はすべて $2 l / \mathrm{min}$ の酸素吸入下にて 施行した。 以上の撮像に要した合計時間は約 15 分程度 であった。

$\mathrm{T} 1$ 強調画像, T2強調画像では周囲肝組織と比較し

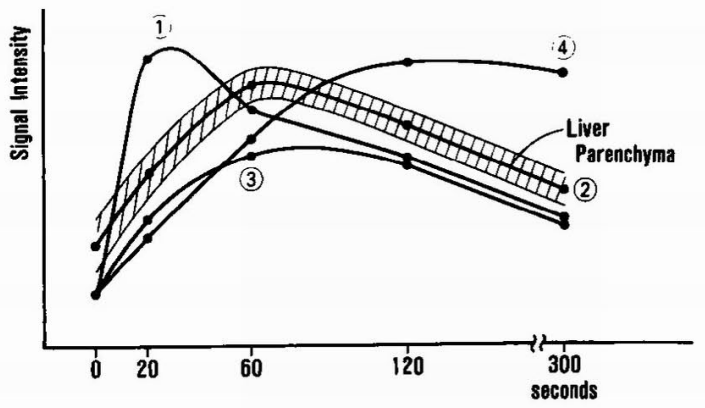

Fig. 1 Classification of Hemodynamics of the Small Hepatic Nodules Determined by Dynamic MRI. (1): hypervascular type, (2): isovascular type, (3): hypovascular type, (4): delayed hyperenhancement type.
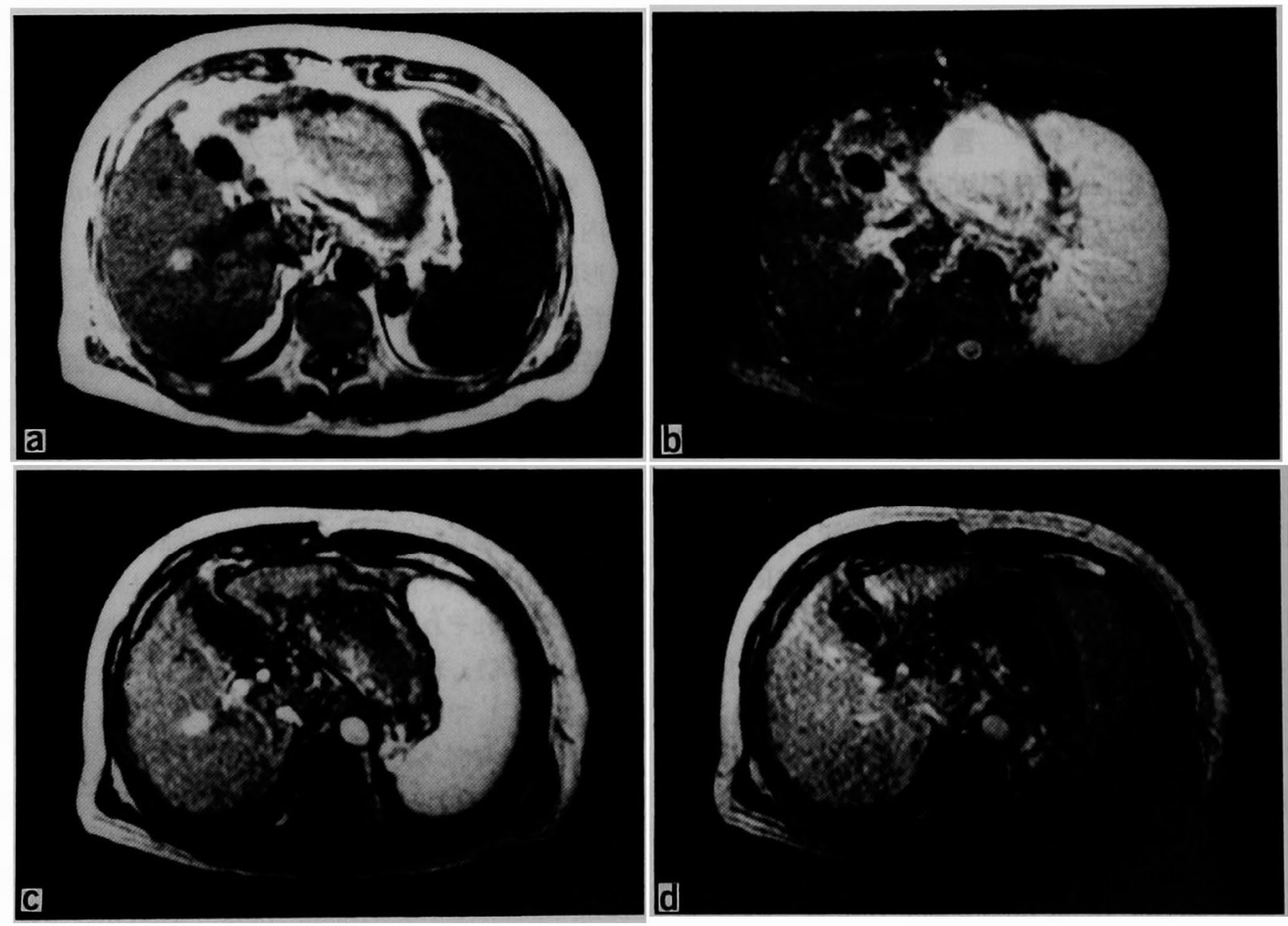

Fig. 2 Small Hpetocellular Carcinoma (a) high intensity lesion on T1-weighted image, (2) iso intensity lesion on T2-weighted image, (c) Dynamic MRI, 20 seconds after Gd-DTPA injection, (d) Dynamic MRI, 5minutes after Gd-DTPA injection. 
て高信号, 等信号, 低信号病変と判定した. ダイナミッ ク MRIでは time intensity curveから周囲肝組織と の対比により濃染パターンにより分類した（Fig. 1). 関心領域の計測部位は結節性病変内におさまる最大の 正方形で行った． 1 型は hypervascular type， 2 型は isovascular type, 3型は hypovascular type, 4 型は delayed hyperenhancement type とした.

$$
\text { 成 績 }
$$

\section{1. 検査可能症例}

130 症例に検査を施行し, 全例, 寸べての検査が可能 であった， 1 例は閉所恐怖症であったが短時間検査で あったため途中で中止せず最後まで検査を終了し得 た. 1 名は造影剤注入後に皮疹が出現したが，数時間 で軽快した。

\section{2. 肝内小結節性病变の高速 MRI による信号強度} 肝細胞癌では(Fig. 2)，T1強調画像において高信号 33 結節 $(42 \%)$ ，等信号34結節 $(44 \%)$, 低信号 11 結節 (14\%)であり，T2強調画像では高信号38結節 (49\%),
等信号38結節 $(49 \%)$ ，低信号 2 結節（3\%）であり， 組み合わせは Table 1 に示すごとく T1強調画像高信 号, T2強調画像等信号が最も多かった。 T1強調画像, T2強調画像のいずれかで検出可能であったのは78結 節中64結節（82\%）であった。

腺腫様過形成ではT1強調画像で高信号 9 結節 (56\%), 等信号 7 結節 (44\%)，T2強調画像で高信号 1 結節 ( $6 \%$ ), 等信号 15 結節 $(94 \%)$, 組み合わせ (Table

Table 1 Signal Intensity Patterns Determined by Fast Spin Echo Method of MRI in patients with Small Hepatocellular Carcinoma.

\begin{tabular}{c|c|c|c}
\hline \multirow{2}{*}{$\begin{array}{c}\text { T1 Weighted Image } \\
\text { (Signal Intensity) }\end{array}$} & \multicolumn{3}{|c}{$\begin{array}{c}\text { T2 Weighted Image } \\
\text { (Signal Intensity) }\end{array}$} \\
\cline { 2 - 4 } & High & Iso & Low \\
\hline High & 9 & 18 & 11 \\
Iso & 24 & 14 & 0 \\
Low & 0 & 2 & 0 \\
\hline
\end{tabular}
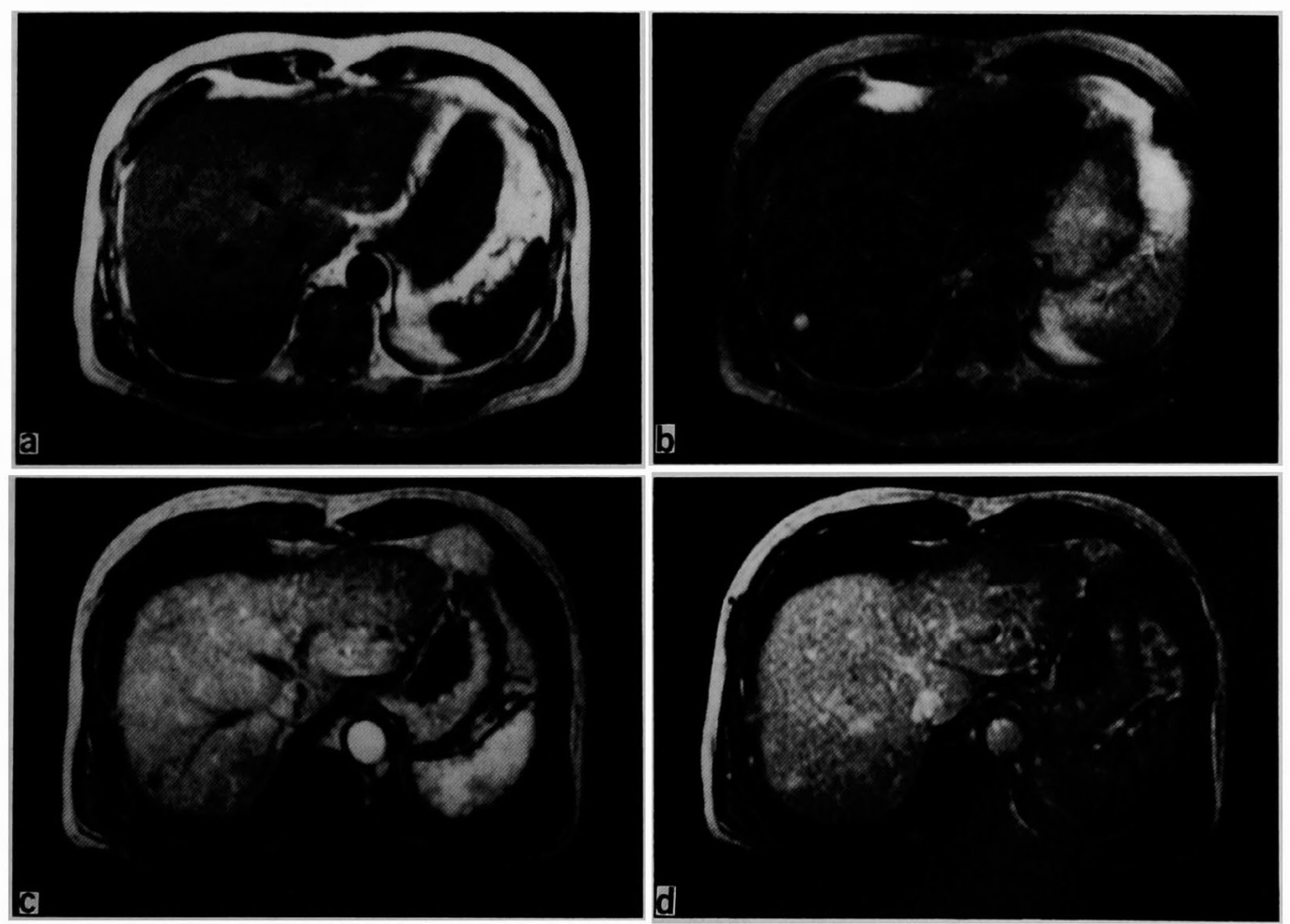

Fig. 3 Cavernous Hemangioma of the Liver (a) Iso intensity lesion on T1-weighted image, (b) High intensity lesion on T2-weighted image (c) low intensity lesion on dynamic MRI of 20 seconds after Gd-DTPA injection, (d) High intensity lesion on dynamic MRI of 5minutes after Gd-DTPA injection. 
Table 2 Signal Intensity Patterns Determined by Fast Spin Echo Method of MRI in patients with Adenomatous Hyperplasia.

\begin{tabular}{c|c|c|c}
\hline \multirow{2}{*}{$\begin{array}{c}\text { T2 Weighted Image } \\
\text { (Signal Intensity) }\end{array}$} & \multicolumn{3}{|c}{$\begin{array}{c}\text { T1 Weighted Image } \\
\text { (Signal Intensity) }\end{array}$} \\
\cline { 2 - 4 } & High & Iso & Low \\
\hline High & 1 & 0 & 0 \\
Iso & 8 & 7 & 0 \\
Low & 0 & 0 & 0 \\
\hline
\end{tabular}

Table 3 Signal Intensity Patterns Determined by Fast Spin Echo Method of MRI in patients with Large Regenarative Nodule.

\begin{tabular}{c|c|c|c}
\hline \multirow{2}{*}{$\begin{array}{c}\text { T2 Weighted Image } \\
\text { (Signal Intensity) }\end{array}$} & \multicolumn{3}{|c}{$\begin{array}{c}\text { T1 Weighted Image } \\
\text { (Signal Intensity) }\end{array}$} \\
\cline { 2 - 4 } & High & Iso & Low \\
\hline High & 0 & 0 & 0 \\
Iso & 5 & 17 & 0 \\
Low & 0 & 3 & 2 \\
\hline
\end{tabular}

2)では T1强調画像高信号，T2強調画像等信号が最も 多く，検出率は56\%であった。

粗大再生結節ではT1強調画像で信号 5 結節 $(19 \%)$ ，等信号 20 結節 $(74 \%)$ ，低信号 2 結節 $(7 \%)$, $\mathrm{T} 2$ 強調画像で等信号22結節 $(81 \%)$ ，低信号 5 結節 (19\%)，組み合わせ (Table 3) では T1強調画像, T2 強調画像ともに等信号病変が多く, 検出率は $37 \%$ で あった。

肝血管腫では (Fig. 3)，T1強調画像で等信号14結節 (48\%)，低信号15結節 $(52 \%) ， \mathrm{~T} 2$ 強調画像で高信号29 結節 $(100 \%) て ゙ あ り ，$ 組み合わせ（Table 4)では T1 強調画像低信号, T2強調画像高信号が多く, 検出率は 100\%であった。
Table 4 Signal Intensity Patterns Determined by Fast Spin Echo Method of MRI in patients with Cavernous Hemangioma.

\begin{tabular}{c|c|c|c}
\hline \multirow{2}{*}{$\begin{array}{c}\text { T2 Weighted Image } \\
\text { (Signal Intensity) }\end{array}$} & \multicolumn{3}{|c}{ T1 Weighted Image } \\
\cline { 2 - 4 } & High & Iso & Low \\
\hline High & 0 & 14 & 15 \\
Iso & 0 & 0 & 0 \\
Low & 0 & 0 & 0 \\
\hline
\end{tabular}

3. ダイナミック MRIによる血流動態 (Table 5) 肝細胞癌78結節では 1 型58結節 $(74 \%) ， 2$ 型18結節 $(23 \%) ， 3$ 型 2 結節 $(3 \%)$ ，腺腫様過形成16結節では 2 型 $100 \%$ ，粗大再生結節 27 結節では 2 型 25 結節 (93\%)，3 型2結節 $(7 \%) ，$ 肝向管腫では 1 型 1 結節 (3\%)，4型28結節 (97\%) であった。

1 型を肝細胞癌型， 4 型老肝血管腫型とすると FMPSPGR 法による小肝紐胞癌の感度は74\%, 特異度 は $98 \%$ であり, 肝血管腫の感度は97\%, 特異度は $100 \%$ であった。

また，FSE法によるT1強調画像，T2強調画像， FMPSPGR 法によるダイナミックMRIを併せた小 肝細胞癌の検出率は92\%であった。

\section{考案}

わが国の肝細胞癌は肝硬変を中心とした慢性肝疾患 から多く発生することはよく知られているところであ る14,15).そこで,これらの慢性肝疾患を対象にした肝癌 のスクリーニング検査が腹部超音波を中心としてなさ れることが多い4,5).これにより，小さな肝細胞癌も多 く発見されるようになってきているが一方, 粗大な再 生結節や腺腫様過形成, 肝血管腫などの肝細胞癌と鑑 別を要する肝内小結節性病変も多く見つかるように

Table 5 Hemodynamics of the Small Hepatic Nodules Determined by Dynamic MRI.

\begin{tabular}{l|c|c|c|c}
\hline \multirow{2}{*}{} & \multicolumn{4}{|c}{ Hemodynamic Petterns } \\
\cline { 2 - 5 } & $\begin{array}{c}1 \\
\text { Hypervascular }\end{array}$ & $\begin{array}{c}2 \\
\text { Isovascular }\end{array}$ & $\begin{array}{c}3 \\
\text { Hypovascular }\end{array}$ & $\begin{array}{c}4 \\
\text { Delayed } \\
\text { Hyperenhancement }\end{array}$ \\
\hline HCC & $58(74 \%)$ & $18(23 \%)$ & $2(3 \%)$ & 0 \\
AH & 0 & $16(100 \%)$ & 0 & 0 \\
LRN & 0 & $25(93 \%)$ & $2(7 \%)$ & 0 \\
HL & $1(3 \%)$ & 0 & 0 & $28(97 \%)$ \\
\hline
\end{tabular}

HCC : Hepatocellular Cacinoma, AH : Adenomatous Hyperplasia, LRN : Large Regenrative Nodule, $\mathrm{CH}$ : Cavernous Hemangioma 
なってきた，その鑑別診断には血管造影や肝生検など の侵襲的な検查へと進むことが多い。

一方, MRI は肝細胞癌や肝血管腫の診断には碓れて

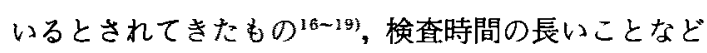
からあまり積極的に肝細蚫癌診断の診断体系に組み込 まれてこなかった。 また，呼吸下の検查であったため， 呼吸などの体動によるアーチファクトも無視できず, 肝内小病変の診断には限界があった。近年, FSE 法や FMPSPGR 法などの高速撮像法が開発され9 息止め検査が可能となった11,12)。これらの方法より MRIにみられた呼吸による体動のアーチファクトを 大幅に軽減できるようになり，検查時間も大幅に短縮 できるようになった．FSE 法はSE 法に比べて ringing artifact, 脂肪が強調される等の問題点もあり, FSE はSEに比べ描出能が悪化するとされるが，アー チファクトに関しては呼吸下検查の方が長い検查時間 での体動によるアーチファクトの影響の方がむしろ強 く出るため，実際には息止めの効果が大きく，息止め によるFSE 法は小型の結節性病変の描出は良好で あった。また，全訮ダイナミック MRI を施行できるよ うになり, 詳細な血流動態の観察も可能となった。こ れまでも肝の結節性病変に関して, 高速 MRIを用い た息止めT2強調画像での検討やダイナミック MRI での検討はなされてきたがFSEによる息止めT1強 調画像はなく, T1強嘼画像, T2強調画像, ダイナミッ ク MRI を組み合わせ,さらに腫瘤径 $20 \mathrm{~mm}$ 以下の肝 内小病変での検討はなかった。

今回我々の検討した，FSE 法による息止めの T1強 調画像, T2強調画像は SE 法に比べて体動によるアー チファクトが大幅に軽減され，小病変が検出可能で あった，今回の検討では酸素吸入下での 20 秒程度の息 止めは肺切除術後等の肝活量の少ない患者が少なくな い慢性肝疾患症例の全例に施行可能であった．高速化 することにより㩆著になるアーチファクトも脂肪抑制 やプレサチュレーションパルス等により軽減でき，明 瞭な画像を作ることが可能であった，SE 法による肝 細胞癌の信号強度のパターンと比較すると ${ }^{201}$, 我々の 検討した症例が腫瘍径 $20 \mathrm{~mm}$ 以下の小さな症例であっ たことも関係していると思われれるがT1強調画像で 高信号, T2強調画像で等信号のものが多い傾向にあっ た. FSE 法は SE 法に比べて脂肪組織が強調されると されており,小肝細胞癌や境界病変では脂肪化の頻度 も稀でなく, T1強調画像では脂肪組織は高信号病変と して描出され，この点でも T1強調画像を FSE 法で撮
像する事は重要と考えられた。

さらにダイナミック MRI を同時に施行すること で単に肝細胞癌の検出のみならず質的䛦断までが可能 であった.ダイナミック MRIにより肝細胞癌と腺腫 様過形成や再生結節などとの鑑別もある程度可能て あった。

肝血管腫に関しても, 従来の SE 法と比較してその 検出感度は良好であった。血管腫は従来の報告のよう に辺緑からゆっくりと内部へと濃染していき，それが 遅い時期まで残るという典型的なパターンをとる症例 は少なく，今回の対象の小型の腫煌ではやや異なって おり，造影剂注入20秒後の早期にはむしろ周囲肝組織 の方がよく造影され，やや遅れて60秒後に腫瘍部分が 一様に溜染し，それが 5 分後まで持続する症例が多 かった。これは腫瘍経 $20 \mathrm{~mm}$ 以下の小型の血管腫の特 徵と思われた。ダイナミック MRIによる血流動態を みることにより大部分の血管腫は確定診断が可能で あった。

元来 MRI は非侵襲性の安全な検査法であったが， 高速 MRI を利用すれば短時間の感度の高い検查とな ク，外来等でも施行可能な検查法と考えられる．腹部 超音波検查は各種画像診断のなかでも訮内小病変の検 出に関しては最も優れるとされるが，質的診断に関し ては困難なことが多い。一方, X 線 CT はへリカル CT の出現により, 小肝癌の診断能の向上がみられるが造 影前の単純 CT のレベルでの検出率は必ずしも多くな い.この点, 高速 MRI では T1強調画像, T2強調画像 と多角化に検討可能であり,より詳細な小病変の検出 が可能であったささらにそそこを目指してダイナミッ ク MRI を施行することで詳紏な血流動態の把握が可 能となり，肝内小結節性病変の質的診断にまでいたる ことが可能であった。 そこで今後注慢性肝疾患で肝の 腫痹性病変が疑われた場合には血管造影や肝生検など の侵襲性の高い検査の前に高速 MRI を施行すべきと 考えられた。ことに血管腫や動脈血流の増加している 肝細胞癌に関してはMRIにて大部分が診断可能と考 えられた。

また，腹部超音波検査は画像診断の中でも肝細胞癌 の検出には優れているが，肝硬変などで萎縮変形した 肝臓では死角も存在する5). 今後は非侵襲的で短時間 で検査可能であり，検出感度も高いMRI は肝癌のス クリーニングにも応用可能と考えられた。 


\section{文献}

1) The Liver Cancer Study Group of Japan. Primary liver cancer in Japan: Clinicopathological features and results of surgical treatment. Ann Surg 211: 277-287, 1990

2) 池田健次, 熊田博光：肝硬変の経過と予後, 日本臨 牀 $52: 63-68,1993$

3) Ikeda K, Saitoh S, Koida I, et al: A multivariate analysis of risk factors for hepatocellular carcinogenesis: A prospective observation of 795 patients with viral and alcoholic cirrhosis. Hepatology 18:47-53, 1993

4）真島康雄：訮細胞癌の早期猃断；超音波に上るス クリーニング. 日内会誌 $84: 1992-1996,1995$

5) 齐藤 聡, 池田健次, 鯉田 勲, 他：肝癌のスクリ ーニング検查としての腹部超音波と X 線 CT の 診断能力と眼界。消化器科 $17: 505-510,1992$

6) Itoh $K$, Nishimura $K$, Togashi $K$, et al: Hepatocellular carcinoma: MR imaging. Radiology $164: 21-25,1987$

7) Matsui O, Kadoya M, Takashima $T$, et al: Adenomatous hyperplastic nodules in the cirr. hotic liver: Differentiation from hepatocellular carcinoma with MR imaging. Radiology 173 : 123-126, 1989

8) Ohtomo K, Itai $Y$, Ohtomo $Y$, et al: Regenerative nodules in hepatic cirrhosis: MR finndings with pathologic correlation. AJR $154: 505-507$, 1990

9) Henning I. Nauerth A, Friedburg H: RAREimaging: A fast imaging method for clinical MR. Magn Reson Med 3: 829-833, 1986

10) Outwater EK, Mitchell DG, Vinitski S: Abdominal MR imaging: Evaluation of a fast spin-echo sequence. Radiology 190:425-429, 1994

11) Rydberg JN, Lomas DJ, Coakley KJ, et al : Comparison of breath-hold fast spin-echo and conventional spin-echo pulse sequences for T2-weighted MR imaging of the liver lesions. Radiology 194:431-437, 1995
12) Low RN, Francis IR, Sigeti JS, et al: Abdominal MR imaging: Comparison of T2-weighted fast and conventional spin-echo, and contrastenhanced fast multiplanar spoiled gradientrecalled imaging. Radiology 186: 803-811, 1993

13) Ikeda K, Saitoh $S$, Koida I, et al: Diagnosis and follow-up of small hepatocellular carcinoma with selective intraarterial digital subtraction angiography. Hepatology 17 : 10031007, 1993

14) Okuda K, Nakashima $T$, Sakamoto $K$, et al : Hepatocellular carcinoma arising in noncirrhotic and highly cirrhosis liver. Cancer 49 : $450-455,1982$

15) Oka H, Kurioka N, Kim K, et al: Prospective study of early detection of hepatocellular carcinoma in patients with cirrhosis. Hepatology $12: 680-687.1990$

16) Itai $Y$, Ohtomo $K$, Furui $S$, et al: Noninvasive diagnosis of small cavernous hemangioma of the liver : Advantage of MRI. AJR 145 : 11951199, 1985

17) Ohtomo $K$, Itai $Y$, Yoshikawa $K$, et al: $\mathrm{He}$ patocellular carcinoma and cavernous hemagioma : Differentiation with MR imaging : Efficacy of $\mathrm{T} 2$ values at 0.35 and $1.5 \mathrm{~T}$. Radiolo gy $168: 621-623,1988$

18) Semelka RC, Brown ED, Ascher SM, et al: Hepatic hemangiomas: A multiinstitutional study of appearance on T2-weighted and serial gadolinium-enhanced gradient-echo MR images. Radiology 192: 401-406, 1994

19) McFarland EG, Mayo-Smith WW, Saini S, et al: Hepatic hemangiomas and malignant tumors: Improved differentiation with heavily T2-weighted conventional spin-echo MR imag. ing. Radiology 193:43-37, 1994

20) Kadoya M, Matsui $O$, Takashima $T$, et al: Hepatocellular carcinoma : Correlation of MR imaging and histopathologic findings. Radiology $183: 819-825,1992$ 


\title{
Diagnosis of small hepatic nodular lesion determined by magnetic resonance imaging (MRI) under breath holding
}

\author{
Satoshi Saitoh, Kenji IKeda, Isao KoIda, Yoshiyuki Suzuki, \\ Masahiro Kobayashi, Akihito Tsubota, Yasuji ARASE, \\ Kazuaki ChayAma, Naoya Murashima \\ and Hiromitsu KUMADA*
}

We examined fast MRI under breath holding in patients with small hepatic nodular lesion. MR imagings were obtained with Fast Spin Echo (FSE) which was T1-weighted image and T2-weighted image and Fast Mutiplnar Spoiled GRASS (FMPSPGR) which was dynamic study. Sixty-four of $78(74 \%)$ patients with small hepatocellular carcinoma ( $\mathrm{HCC}$ ) were detected by FSE sequence. Nine of $16(56 \%)$, nine of $26(37 \%)$ and 29 of $29(100 \%)$ patients with adenomatous hyperplasia, large regenerative nodule and cavernous hemangioma were detedcted by FSE sequence, respectively. Fifity-seven (74\%) HCC lesions and 28 (97\%) adenomatous hyplasia lesions were diagnosed by FMPSPGR sequence, respectively. Fast MRI (FSE and FMPSPGR) with breath holding provides diagnostically useful small nodular lesion of the liver.

* Department of Gastroenterology Toranomon Hospital (Tokyo) 